\author{
Amythia Lapadca Mirzah', Ahmad Nur Sheha Gunawan², Santi Salayanti ${ }^{3}$ \\ Universitas Telkom \\ 1amythiamirzah@yahoo.com, \\ 2ahmadnursheha@gmail.com, \\ 3 salayanti@gmail.com
}

\title{
PENERAPAN PENCAHAYAAN BUATAN PADA INTERIOR RESTORAN ATMOSPHERE BANDUNG DI MALAM HARI
}

\begin{abstract}
Abstrak Restoran Atmosphere merupakan salah satu tempat makan keluarga yang sering didatangi masyarakat kota maupun luar kota Bandung. Salah satu hal yang mempengaruhi kedatangan masyarakat kota Bandung untuk makan di restoran atmosphere adalah suasana restoran. Pengaruh yang menciptakan suasana yang cozzy di restoran Atmosphere salah satunya dengan menggunakan pencahayaan yang dapat berpengaruh pada suasana dan kenyamanan pengguna restoran itu sendiri. Aktivitas pengunjung dan pengelola yang berada pada restoran seperti makan, berkumpul, menyajikan makanan sangat dipengaruhi oleh pencahayaan yang ada. Pencahayaan lampu dapat memberikan kesan dan efek yang berbeda-beda sesuai dengan jenis dan penerapan lampu yang ada, seperti efek nyaman dengan kesan hangat pada restoran Atmosphere. Pencahayaan juga dapat memberikan ciri khas tersendiri mengikuti tema dan gaya yang diterapkan pada interiornya. Dengan analisa deskriptif maka penelitian ini dilakukan untuk melihat pengaruh sistem pencahayaan terhadap efek atau kesan tertentu dan sesuai standar kenyamanan yang ada pada restoran Atmoshpere. menggunakan kajian literature, observasi dan pengumpulan data melalui wawancara, maka peneliti memperoleh hasil kajian penerapan cahaya interior pada restaurant Atmosphere yang berada Jalan Lengkong Besar No.97.
\end{abstract}

Kata kunci: Restoran, pencahayaan, suasana interior, persepsi psikologi.

\begin{abstract}
Restaurant Atmosphere is one of the family dining place that is often visited by the inside and outside community of Bandung. One of the things that influence the arrival of the people of Bandung to eat in the restaurant atmosphere is the atmosphere of the restaurant. The influence that creates a cozzy atmosphere in Restaurant Atmosphere one of them is by using lighting that can affect the atmosphere and comfort of the user of the restaurant itself. Activities of visitors and managers who are in restaurants such as eating, gathering, serving food are strongly influenced by the existing lighting. Lighting can provide different impressions and effects according to the type and application of existing lights, such as the cozy effect with warm impression on Atmosphere restaurants. Lighting can also provide its own characteristics following the theme and style applied to the interior. With descriptive analysis, this research is done to see the effect of lighting system to certain effect or impression and according to the standard of comfort that exist in Atmoshpere restaurant. using literature review, observation and data collection through interviews, then the researchers obtained the results of the study of the application of interior light on restaurant Atmosphere located Lengkong Besar Besar No.97.
\end{abstract}

Keywords: Restaurant, lighting, interior atmosphere, psychological perception.

\section{Pendahuluan}

\subsection{Latar Belakang}

Banyak hal yang menjadi daya tarik dan kesuksesan sebuah restoran, seperti citarasa makanan, pelayanan, lokasi dan image atau suasana. Atmosphere atau suasana terencana yang sesuai pasar sasarannya akan dapat menarik konsumen untuk membeli (Kotler, 2005). Liberman (2002) menyatakan bahwa interior sebuah restoran akan menentukan restoran tersebut dapat bertahan atau tidak. Salah satu daya tarik restoran adalah penciptaan suasanana 
interior dengan memanfaatkan desain pencahayaaan. Pendukung desain sistem pencahayaan dalam unsur elemen interior yang menjadi salah satu hal yang mempengaruhi suasana adalah warna dan bentuk. Santen dan Hansen (1985) menyatakan bahwa bentuk dan warna tidak dapat dipisahkan serta sangat terikat dengan cahaya, bekerja dengan bentuk berarti pula bekerja dengan cahaya, warna elemen pembatas ruang dan warna cahaya berperan sangat penting. Dengan demikian berbagai macam cara penyinaran yang dihasilkan oleh cahaya buatan dapat menciptakan suasana tertentu yang dapat menggugah perasaan, emosi, kenyamanan seseorang dan juga aktivitas orang tersebut.

Restoran Atmosphere adalah rumah makan dengan konsep gaya Bali ditunjukan dengan elemen-elemen estetis didalamnya yang mengadopsi elemen Bali guna menghadirkan suasana Bali. Guna menguatkan image nuansa suasana Bali, restoran Atmosphere menggunakan desain pencahayaaan sebagai salah satu cara untuk mengahadirkan nuansa Bali. Caranya dengan menggunakan warna hangat yang bersahabat pada pencahayaan buatannya. Warna itu diterapkan pada pencahayaan umum maupun pencahayaan khusus restoran tersebut.

Penemuan yang didapat dari hasil wawancara dengan pengunjung restoran ini adalah pencahayaan yang digunakan merupakan salah satu daya tarik dari restoran. Penerapan cahaya pada restoran memberikan efek dan kesan tertentu sesuai dengan jenis lampu yang digunakan, yang dimana pada restoran ini memberikan kesan hangat dengan pemakaian warna lampu warm light.

Hasil survey dapat menunjukan zona - zona yang diminati oleh pengunjung terkait dengan desain dan tata letak sistem pencahayaan pada restoran atmoshpere. Hal ini menjadi hipotesa sementara kaitan antara desain sistem pencahayaan terhadap minat dan posisi letak pengunjung di restoran itu.

Pencahayaan buatan yang diteliti dilakukan pada malam hari dikarenakan cahaya buatan yang digunakan pada restoran Atmosphere hanya digunakan pada malam hari dan jumlah pengunjung paling banyak beraktifitas berjumlah 69\% mulai dari jam 16.00 sampai 22.00 WIB.

Metode yang digunakan untuk penelitian ini berupa studi literatur, survei, wawancara, observasi, pengukuran dan dokumentasi. Metode yang digunakan berguna untuk mengetahui gambaran dari kelebihan dan kekurangan pencahayaan yang digunakan pada restoran Atmosphere yang kemudiana dianalisa apakah ada korelasi antara desain sistem pencahayaaan dengan minat kunjungan konsumen yang dapat dilihat dari posisi tempat duduk.

\subsection{Kondisi Existing}

Bangunan Restoran Atmosphere mendapatkan cahaya matahari yang cukup pada siang hari. Arah depan restoran menghadap ke arah barat, sehingga bagian belakang (timur), kiri (selatan) dan kanan (utara) restoran bisa mendapatkan cahaya matahari yang cukup. Sedangkan pada sore hari bagian depan (barat), kiri (selatan) dan kanan (utara) restoran mendapatkan sinar matahari sore yang berlebih tetapi hal ini diatasi dengan penggunaan fasade masih sebagai penghalang paparan lebih sinar matahari. Restoran Atmosphere mempunyai bukaan bangunan depan dan belakang yang luas, cahaya matahari sore dan pagi bisa masuk dengan masksimal. 


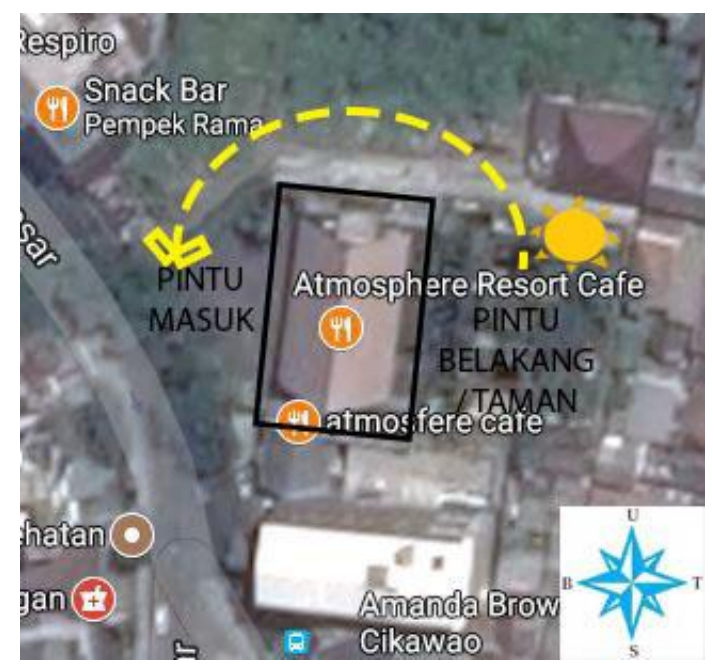

Gambar (1.1) Lokasi restoran Atmosphere

Sumber: Google.com, 2017

Restoran Atmosphere terdiri dari dua lantai. Lantai satu memiliki luas yang sama dengan lantai dua, yaitu panjang 21 meter dengan lebar 12 meter, dan luas ruang interior restoran lantai satu dan lantai dua $252 \mathrm{~m} 2$. Pada lantai pertama terdapat area makan keluarga bersama dengan fasilitas bar, piano, dan panggung kecil. Pencahayaan pada lantai satu termasuk pencahayaan yang cukup terang dimana pengunjung dapat melihat pemandangan sekitar dengan jelas.

Pada lantai dua merupakan area makan keluarga dengan bentuk duduk dan lesehan. Pencahayaan pada lantai dua tidak terlalu terang, dan kebanyakan cahaya yang ada berupa cahaya yang memberikan efek remang-remang di area sekitarnya.

\section{Kajian Literatur}

\subsection{Jenis Pencahayaan Buatan}

Dalam bukunya Darmasetiawan, Christian, dan Lestari Puspakesuma. (1991) yang berjudul Teknik Pencahayaan dan Tata Letak Lampu Jilid 1 Pengetahuan Dasar, klasifikasi pencahayaan buatan terdapat sebagai berikut:

- Pencahayaan Buatan

Pencahayaan buatan adalah pencahayaan yang dihasilkan oleh sumber cahaya selain cahaya alami. Pencahayaan buatan sangat diperlukan apabila posisi ruangan sulit dicapai oleh pencahayaan alami atau saat pencahayaan alami tidak mencukupi. Fungsi pokok pencahayaan buatan baik yang diterapkan secara tersendiri maupun yang dikombinasikan dengan pencahayaan alami adalah sebagai berikut:

- Menciptakan lingkungan yang memungkinkan penghuni melihat secara detail serta terlaksananya tugas serta kegiatan visual secara mudah dan tepat

- Memungkinkan penghuni berjalan dan bergerak secara mudah dan aman

- Tidak menimbukan pertambahan suhu udara yang berlebihan pada tempat kerja

- Memberikan pencahayaan dengan intensitas yang tetap menyebar secara merata, tidak berkedip, tidak menyilaukan, dan tidak menimbulkan bayang-bayang. 
- Meningkatkan lingkungan visual yang nyaman dan meningkatkan prestasi.

- Seberapa jauh pencahayaan buatan akan digunakan, baik untuk menunjang dan melengkapi pencahayaan alami.

- Tingkat pencahayaan yang diinginkan, baik untuk pencahayaan tempat kerja yang memerlukan tugas visual tertentu atau hanya untuk pencahayaan umum

- Warna yang akan dipergunakan dalam ruangan serta efek warna dari cahaya

Penerapan pencahayaan buatan yang sering dipergunakan secara umum dapat dibedakan atas tiga macam yakni:

\section{(1) Penerapan Pencahayaan Merata}

Pada sistem ini iluminasi cahaya tersebar secara merata di seluruh ruangan. Penerapan pencahayaan ini cocok untuk ruangan yang tidak dipergunakan untuk melakukan tugas visual khusus. Pada sistem ini sejumlah armatur ditempatkan secara teratur di seluruh langi-langit.

\section{(2) Penerapan Pencahayaan Terarah}

Pada sistem ini seluruh ruangan memperoleh pencahayaan dari salah satu arah tertentu. Sistem ini cocok untuk pameran suatu objek karena akan tampak lebih jelas. Lebih dari itu, pencahayaan terarah yang menyoroti satu objek tersebut berperan sebagai sumber cahaya sekunder untuk ruangan sekitar, yakni melalui mekanisme pemantulan cahaya. Sistem ini dapat juga digabungkan dengan penerapan pencahayaan merata karena bermanfaat mengurangi efek menjemukan yang mungkin ditimbulkan oleh pencahayaan merata.

\section{(3) Penerapan pencahayaan Setempat}

Pada sistem ini cahaya dikonsentrasikan pada suatu objek tertentu misalnya tempat kerja yang memerlukan tugas visual.

\subsection{Warna pada Pencahayaan}

Lampu bisa memberikan efek warna tertentu sesuai dengan temperature warna yang dimiliki oleh lampu tersebut. Dalam pengelompokan warna sesuai standar SNI 03-2001 maka warna dibagi menjadi tiga kelompok:

-Temperatur warna $<3300$ Kelvin

-Temperatur warna 3300 - 5300 Kelvin

-Temperatur warna $<5300$ Kelvin
: Warna hangat

: Warna sedang

: Warna dingin

Untuk medapatkan kenyamanan yang ingin diperoleh maka tingkat pencahayaan merupakan salah satu pengaruhnya karena tingkat pencahayaan akan memberi pengaruh dalam memberikan warna pada lampu tertentu. Jika semakin tinggi tingkat pencahayaan yang diperlukan, maka makin sejuk tampak warna yang dipilih sehingga tercipta pencahayaan yang nyaman.

Warna dari psikologi mempunyai pengaruh terhadap manusia, contohnya suasana hati dan emosi bisa menjadi panas atau dingin, bisa membuat tenang atau mengairahkan. Cahaya yang masuk melalui mata bisa menjadi sebuah sensasi yang dihasilkan dari otak. Contoh sensasi tersebut berupa ruang yang mempunyai warna putih atau lembut bisa memberi kesan 
bahwa ruang lebih besar. Hal sebaliknya akan terjadi jika ruang menggunakan warna-warna gelap. Dilihat dari efek warna terhadap kejiwaan dan sifat khas yang dimilikinya, warna dikelompokan menjadi dua kategori yaitu golongan warna panas dan golongan warna dingin. Diantara keduanya ada yang disebut warna antara atau 'intermediates'. Menurut skema warna psikologi yang berasal dari sistem lingkaran warna Oswald dapat dilihat dengan jelas golongan warna panas berpuncak pada warna jingga $(\mathrm{J})$, dan warna dingin berpuncak pada warna biru kehijauan (BH). Warna panas atau hangat berupa warna yang dekat dengan warna jingga atau merah, sedangkan warna golongan sejuk atau sejuk berupa warna yang berdekatan dengan warna biru kehijauan.

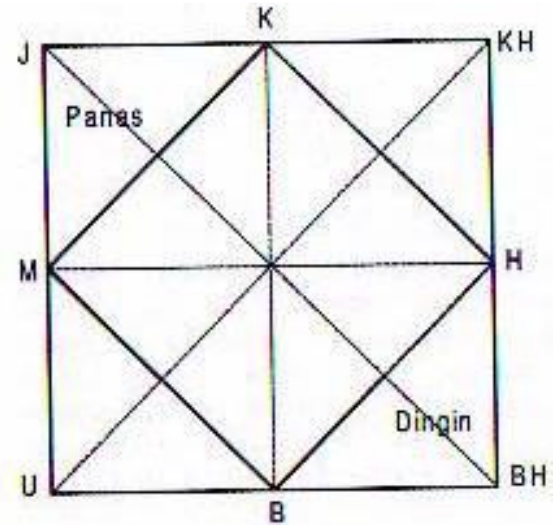

Gambar (2.1) Skema psikologi warna

Sumber: Sulasmi, 2002

Efek psikologis golongan warna panas, seperti merah, jingga, dan kuning memberi pengaruh efek seperti panas, menggairahkan atau mengembirakan. Sedangkan warna golongan warna dingin seperti hijau dan biru dapat memberikan efek psikologis tenang, damai. Untuk warna lain seperti warna ungu dapat memberi efek sedih. Warna bersih memberikan efek bersih dan steril, warna hitam memberi efek formal, berat dan tidak menyenangkan (Pile, 1995 dan Birren, 1961).

\subsection{Pengaruh Umum Sistem Pencahayaan Buatan terhadap Psikologi Manusia}

Pencahayaan buatan beda dengan pencahayaan alami. Cahaya buatan memilki sistem sendiri saat menerangi ruangan. Cahaya buatan memiliki sistem penerangan tersendiri yang bertujuan untuk tercapainya efektivitas dan efisiensi pemanfaatan cahaya buatan di dalam ruangan. Sistem itu terbagi dua, yaitu:

\section{Sistem Lighting Primer}

a. General Lighting (Down lighting): sistem pencahayaan umum ini memberikan pencahayaan merata pada suatu bidang dengan derajat yang sama. Keuntungan dari sistem bisa menampilkan felksibilitas pada area kerja dan kerugiannya efesiensi cahaya bisa rendah karena area kerja menerima cahaya sama besarnya dengan area lainnya.

b. Localized Lighting (Free Standing Up Lighter): Seperti pada pencahayaan umum, pencahayaan setempat juga mengiluminasi area namun dengan luminer yang telah diatur secara fungsional untuk area kerja.

c. General Lighting dan Localized Lighting: Sistem ini digunakan dalam ruangan yang membutuhkan intensitas cahaya dengan lux tertentu. Cara lebih ekonomis dan memberikan cahaya lebih besar pada area kerja yang membutuhkan. 


\section{Sistem Lighting Sekunder}

a. Ambient Light: sistem penerangan dengan sinar merata (difuse).

b. Accent Light: sistem penerangan yang sinarnya berfungsi sebagai aksen. Pencahayaan ini dapat menonjolkan suatu benda.

c. Task Light: sistem penerangan yang sinarnya bertujuan fungsional, misalnya untuk membaca.

d. Effect Light: sistem penerangan yang menyerupai accent light, tetapi objek dan cahaya menjadi pusat perhatian.

e. Decorative Light: sistem penerangan yang bentuknya sebagai unsur dekoratif interior dengan intensitas dan warna cahaya untuk sebagai media pendukung olahan atau karya arsitektur (disebut juga structural light).

\section{f. Architecture Light:}

1. Pencahayaan cove: memberikan pencahayaan ambient dan halus, pencahayaan ini memberikan perasaan luasnya ruang karena permukaan yang terang.

2. Pencahayaan coffer: berupa kantung pada plafon yang dapat diiluminasi dengan beberapa cara.

3. Pencahayaan dinding:

-Pencahayaan valance: yang mengiluminasi bidang atas dan bawah dinding

-Pencahayaan cornice: pencahayaan yang iluminasinya berasal dari atas dinding, atau berasal dari plafon.

f. Mood Light: Pencahayaan yang menampilkan suasana tertentu pada suatu ruang. Contohnya warna kuning memberikan kesan hagat dan akrab, dan warna putih memberikan kesan dingin dan kaku.

Ada teknik pembagian berkas cahaya atau distribusi cahaya dalam sistem pencahayaan buatan. Berkas cahaya tersebut berasal dari armatur lampu. Jenis-jenis armatur lampu yaitu:

\section{Indirect}

Armatur ini mengarahkan lebih dari $90 \%$ cahaya ke atas dengan memanfaatkan langit-langit sebagai pemantul. Dipakai pada bidang yang mempunyai daya reflektansi cukup besar. Keuntungan sistem ini adalah tidak menimbulkan bayangan dan kesilauan sedangkan kerugiannya mengurangi effisien cahaya total yang jatuh pada permukaan kerja.

\section{Semi Indirect}

Armatur ini menyerupai jenis armature indirect, lebih dari 60\% cahaya lampu diarahkan ke atas, sekaligus mengarahkan $40 \%$ cahaya ke bawah. Pada sistem ini masalah bayangan praktis tidak ada serta kesilauan dapat dikurang.

\section{Semi Direct}

Armatur ini mengarahkan cahaya yang sama kuatnya ke arah atas dan arah bawah.

\section{Direct}

Armatur ini mengarahkan cahaya lebih dari $90 \%$ ke arah bawah. Sistem ini dinilai paling efektif dalam mengatur pencahayaan, tetapi ada kelemahannya karena dapat menimbulkan bahaya serta kesilauan yang mengganggu, baik karena penyinaran langsung maupun karena pantulan cahaya. Untuk efek yang optimal, disarankan langi - langit, dinding serta benda yang ada didalam ruangan perlu diberi warna cerah agar tampak menyegarkan. 


\section{Diffused}

Armatur ini menyebarkan cahaya secara merata ke segala arah. Dalam pencahayaan sistem ini termasuk sistem direct - indirect yakni memancarkan setengah cahaya ke bawah dan sisanya keatas. Pada sistem ini masalah bayangan dan kesilauan masih ditemui.

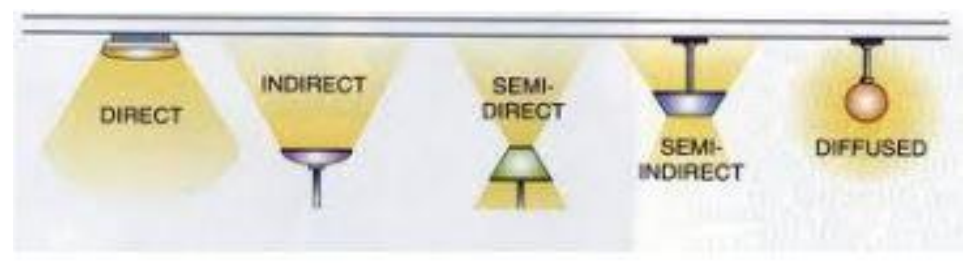

Gambar (2.2) Teknik pendistribusian cahaya

Sumber: Philips Methods of light dispersement, 2017

Intensitas cahaya juga dapat memberikan dampak psikologis yang beragam seperti :

- Cahaya terang.

Cahaya ini dapat menyebabkan efek semangat dalam melakukan sesuatu, sehingga cahaya ini sering digunakan pada area berkumpul atau tempat kegiatan yang membutuhkan fokus yang kuat.

- Cahaya redup.

Cahaya redup dapat meciptakan keakraban sehingga memberikan kesan rileks, tenang dan romantis, sehingga sangat cocok untuk digunakan pada ruang interior untuk relaksasi seperti kamar tidur maupun ruang makan. Cahaya ini sering digunakan untuk kegiatan pribadi terutama oleh pasangan.

- Cahaya yang terlalu terang.

Jenis pencahayaan ini juga sangat berguna untuk meningkatkan tampilan lukisan, patung, atau sudut ruang lain dengan lampu sorot. Tetapi cahaya yang terlalu terang dapat menyebabkan efek bosan dan silau.

- Cahaya dengan warna hangat.

Cahaya yang berwarna hangat seperti warna merah, jingga dan kuning akan membawa suasana riang dan 'welcome', terutama untuk warna orange dan kuning, sehingga bisa menarik perhatian seseorang. Dari hal tersebut maka cahaya ini sering digunakan pada bagunan retail ataupun restoran.

- Cahaya dengan warna dingin.

Cahaya biru, hijau dan ungu bisa membawa kesan tenang dari sisi warna, juga membawa kesan 'dingin'. Warna hijau meberikan rasa nyaman, warna ungu memberikan efek mediatif, warna biru memberikan efek ketenangan. Dari efek tersebut cahaya ini bisa digunakan untuk menghilangkan stress dan perasaan gelisah seseorang. 


\subsection{Silau dan Kenyamanan Visual}

Silau merupakan gangguan yang mempengaruhi performa visual. Ada dua silau yang dapat merugikan kemampuan melihat, yaitu:

- Silau langsung, yaitu silau yang disebabkan sumber cahaya yang terlalu terang sehingga menganggung dan menimbulkan rasa tidak nyaman untuk performa visual. Cahaya langsung juga merupakan konsekuensi geometri dimana semakin dekat sumber cahaya dekat pusat penglihatan, akan menghasilkan silau yang semakin buruk.

- Silau pantulan, yaitu silau yang dihasilkan dari pantulan cahaya pada permukaan yang dipoles atau mengkilat. Masalah ini dapat diatasi dengan memakai bahan material permukaan yang kena cahaya dengan bahan matte dan meletakan sumber cahaya sedemikian rupa agar pancaran yang dipantulkan menjauh dari yang melihat.
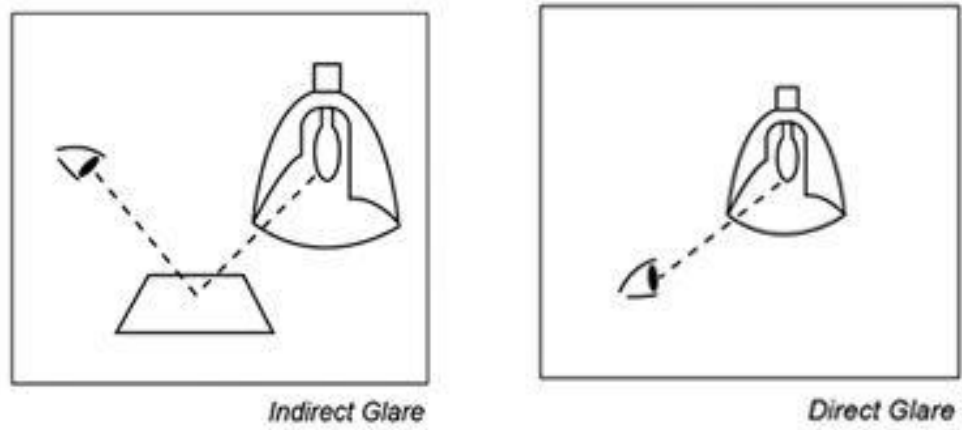

Gambar (2.3) Teknik pendistribusian cahaya

Sumber: Philips Methods of light dispersement, 2017

\subsection{Persyaratan Tingkat Pencahayaan Dalam Ruang}

Berikut table tingkat pencahayaan minimum dan renderasi warna yang direkomendasikan pada ruang makan dan restoran adalah:

Tabel (2.1) Tingkat pencahayaan minimum dan renderasi warna restoran

Sumber: SNI pencahayaan buatan, 2001

\begin{tabular}{|l|c|c|l|}
\hline \multicolumn{1}{|c|}{ Fungsi ruangan } & $\begin{array}{c}\text { Tingkat } \\
\text { Pencahayaan } \\
\text { (lux) }\end{array}$ & $\begin{array}{c}\text { Kelompok } \\
\text { renderasi } \\
\text { warna }\end{array}$ & \multicolumn{1}{|c|}{ Keterangan } \\
\hline Ruang makan & $120 \sim 250$ & 1 atau 2 & - \\
\hline Lobby, koridor & 100 & 1 & $\begin{array}{l}\text { Pencahayaan pada bidang vertikal sangat } \\
\text { penting untuk menciptakan suasana atau } \\
\text { kesan ruang yang baik. }\end{array}$ \\
\hline Cafetaria. & 250 & 1 & \\
\hline $\begin{array}{l}\text { Ruang pamer dengan obyek } \\
\text { berukuran besar (misalnya } \\
\text { mobil). }\end{array}$ & 500 & 1 & $\begin{array}{l}\text { Tingkat pencahayaan ini harus di-penuhi } \\
\text { pada lantai. Untuk beberapa produk } \\
\text { tingkat pencahayaan pada bidang vertikal } \\
\text { juga penting. }\end{array}$ \\
\hline
\end{tabular}




\section{Metode Penelitian}

\subsection{Observasi}

Peneliti mengamati kondisi eksisting dan langsung melihat kondisi restoran dengan melihat suasana dan perilaku pengunjung, serta fenomena-fenomena yang ada disekitar restoran. Salah satu hal yang diobservasi seperti orientasi restoran, jumlah armature, besaran bukaan jendela, dan lain-lain.

\subsection{Wawancara dan Quisioner}

Proses ini dilakukan dengan mendapatkan informasi langsung dari persepsi pengunjung restoran yang ada. Pengunjung mengisi pertanyaan yang dibuat berdasarkan dengan kajian literatur dan daftar pustaka yang ada sehingga bisa dilihat presepsi pengunjung yang menggunakan restoran tersebut. Narasumber berupa pengunjung yang makan di restoran Atmosphere yang menggunakan restoran terutama pada malam hari. Semua narasumber berjumlah 40 orang. Kusioner berupa informasi seperti:

-kesan keterangan cahaya lampu pada malam hari

-kenyamanan lampu yang digunakan pada restoran

-Efek cahaya yang dirasakan oleh pengunjung

\subsection{Pengukuran}

Pengukuran yang berguna sebagai informasi untuk penelitian berupa luas area dan ukuran jendela dan bukaan yang ada pada restoran. Mengukur area interior ruang makan restoran yang ada dan mengukur titik-titik lampu dan jenis armature yang ada pada restoran. Membagi zona sesuai dengan letak titik lampu pada restoran.

\section{Objek Penelitian}

A. Pencahayaan Umum (General Lighting).

Pada area restoran biasanya tidak memiliki pencahayaan yang sama dengan pencahayaan seperti kantor, kelas, perpustakaan ataupun ruang baca lainnya. Pada ruang yang seperti itu memerlukan cahaya yang menghasilkan lux yang sama sesuai dengan standar kenyamanan pada seluruh bagian ruang, sedangkan untuk restoran dengan tema dan konsep tertentu hanya memerlukan cahaya tertentu saja.

Pada restoran Atmosphere terdapat dua area makan yaitu lantai satu dan lantai dua. Dari dua area makan tersebut yang memiliki pencahayaan yang terang dan pencahayaan khusus yang banyak adalah bagian area lantai satu. Sedangkan area lantai dua cahaya umumnya didapati dari bias-bias berkas sinar spotlight yang memancar dari pantulan ceiling restoran, kolom, dan material-material yang lain. Pencahayaan bagian lantai dua kurang begitu terang karena cahaya yang difungsikan untuk pencahayaan khusus memiliki jangkauan cahaya yang tidak terlalu lebar sehingga suasana lebih gelap jika tidak memiliki pencahayaan umum. Pencahayaan ini terjadi saat malam hari dimana suasana disekitar restoran sudah mulai gelap. 

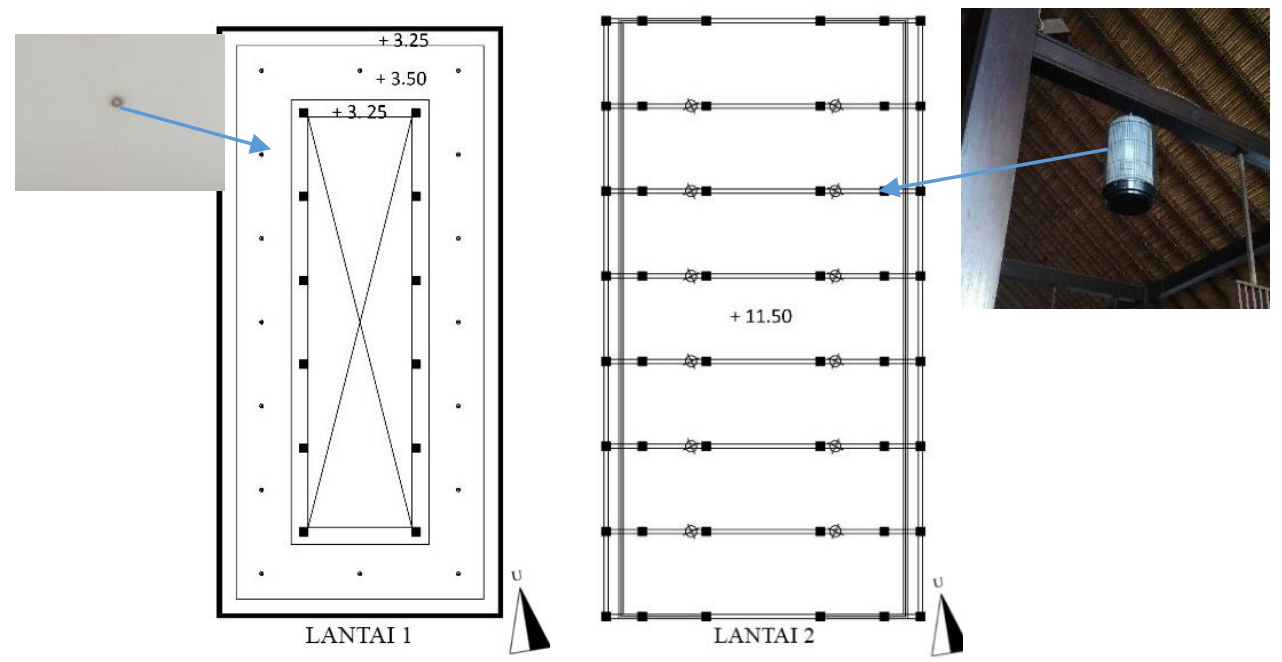

Gambar (4.1) Layout ceiling penempatan cahaya umum

Sumber: Penulis, 2017

Pencahayaan umum pada lantai satu berupa down light dengan warna lampu warm white. Untuk lantai dua cahaya umunya adalah lampu gantung dengan cahaya warna warm white dan berbentuk tabung dengan bahan besi dan kertas sebagai armatur. Untuk cahaya umum biasanya armatur lampu tidak diperlihatkan sebisa mungkin sumber cahayanya, tetapi pada lantai dua sumber pencahayaannya justru diperlihatkan. Walaupun sumber cahaya diperlihatkan tetapi cahaya tidak langsung sampai dimata karena armatur yang dipakai untuk lampu ini memakai elemen buram yang bisa membiaskan cahaya.

B. Pencahayaan Khusus

Berikut macam-macam armatur dan lampu yang digunakan sebagai pencahayaan khusus yang ada di interior restoran Atmosphere. 

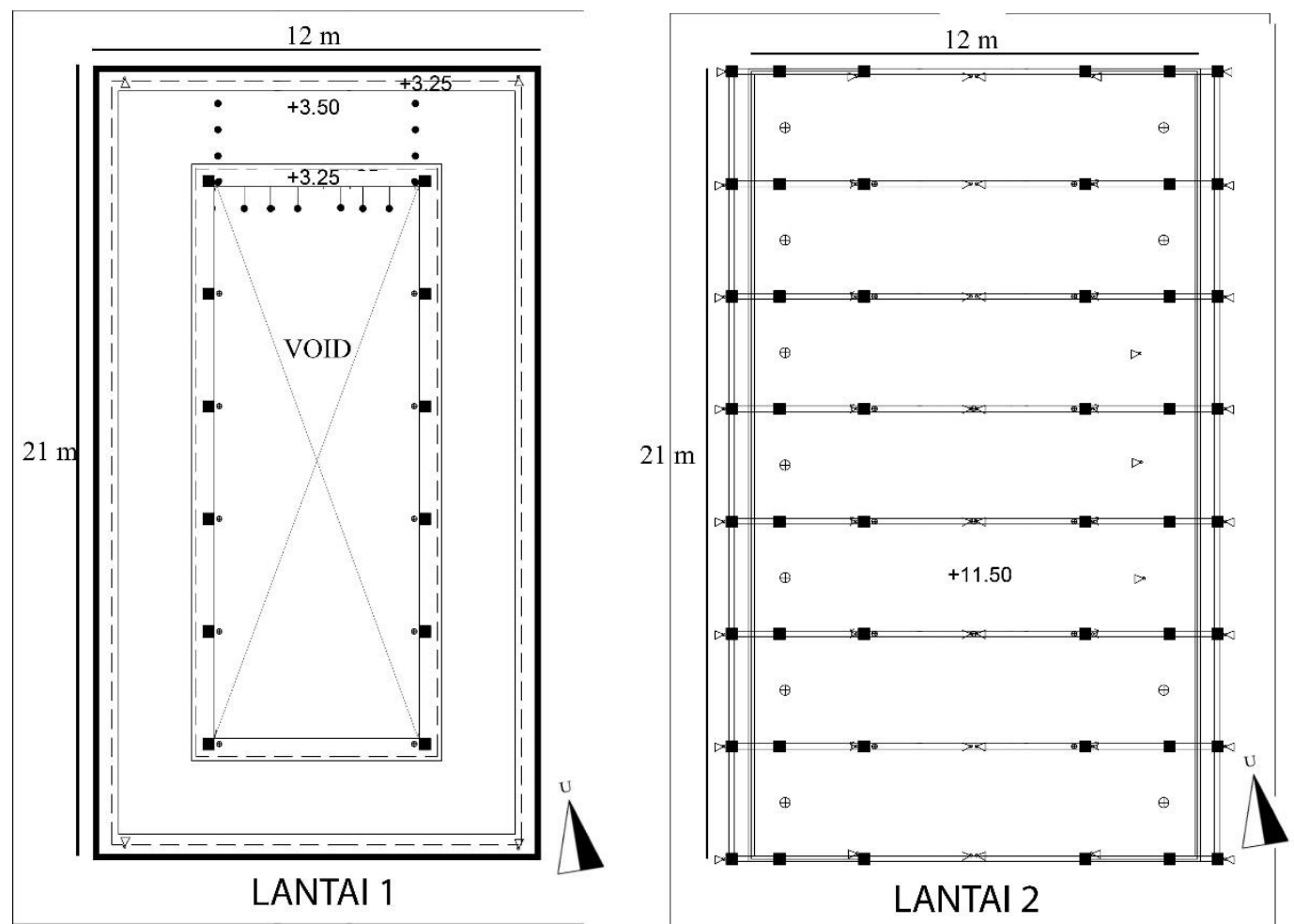

Gambar (4.2) Layout ceiling penempatan cahaya khusus Sumber: Penulis, 2017

\begin{tabular}{|c|c|c|c|c|}
\hline Hasil dari survey & $\begin{array}{l}\text { Notasi } \\
\text { Lampu }\end{array}$ & $\begin{array}{l}\text { Jenis lampu dan } \\
\text { armature }\end{array}$ & Warna lampu & Keterangan \\
\hline & --- & $\begin{array}{l}\text { LED Strip, semi } \\
\text { langsung }\end{array}$ & $\begin{array}{l}\text { Warna kuning } \\
\text { dengan kesan } \\
\text { hangat }\end{array}$ & $\begin{array}{l}\text { Berada di lantai } \\
\text { satu disisi tiap } \\
\text { ruang }\end{array}$ \\
\hline & & $\begin{array}{l}\text { Spot light, langsung } \\
\text { dan tidak langsung }\end{array}$ & $\begin{array}{l}\text { Warna kuning } \\
\text { dengan kesan } \\
\text { hangat }\end{array}$ & $\begin{array}{l}\text { Pada lantai satu } \\
\text { berada ditengah } \\
\text { ruang dan tiap } \\
\text { ujung sisi ruang } \\
\text { Di lantai dua } \\
\text { pada area } \\
\text { loteng. }\end{array}$ \\
\hline & & $\begin{array}{l}\text { Wall lamp, semi } \\
\text { langsung }\end{array}$ & $\begin{array}{l}\text { Warna kuning } \\
\text { dengan kesan } \\
\text { hangat }\end{array}$ & $\begin{array}{l}\text { Berada ditiap } \\
\text { kolom lantai } \\
\text { satu dan dua }\end{array}$ \\
\hline & & $\begin{array}{l}\text { Pendant light, } \\
\text { langsung }\end{array}$ & $\begin{array}{l}\text { Warna kuning } \\
\text { dengan kesan } \\
\text { hangat }\end{array}$ & $\begin{array}{l}\text { Berada di area } \\
\text { bar lantai satu } \\
\text { dan meja } \\
\text { lesehan lantai } \\
\text { dua }\end{array}$ \\
\hline
\end{tabular}

Tabel (4.1) Keterangan lampu area ruang makan lantai satu dan dua Sumber: Penulis, 2017

Daerah makan yang ada pada restoran: 

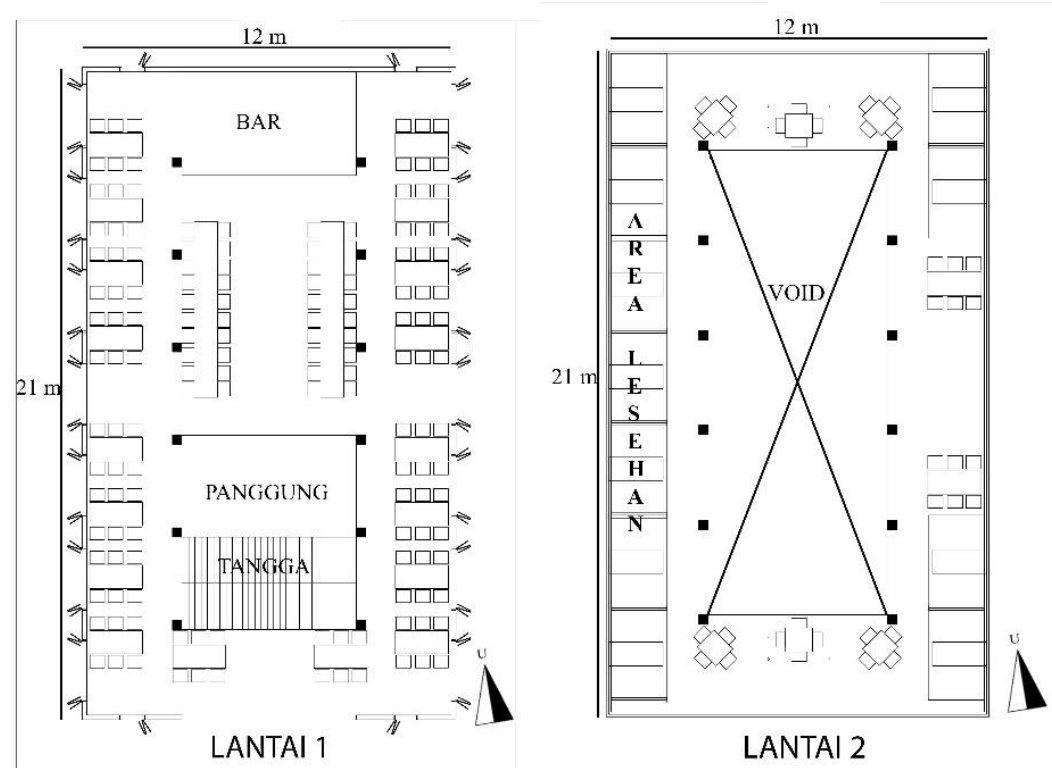

Gambar (4.3) Daerah makan pada restoran

Sumber: Penulis, 2017

\section{Analisa Pencahayaan Pada Interior Restoran Atmosphere}

\subsection{Subjek Penelitian}

Berdasarkan hasil dari pengamatan dan wawancara yang dilakukan oleh penulis di restoran Atmosphere mendapatakan hasil berupa:

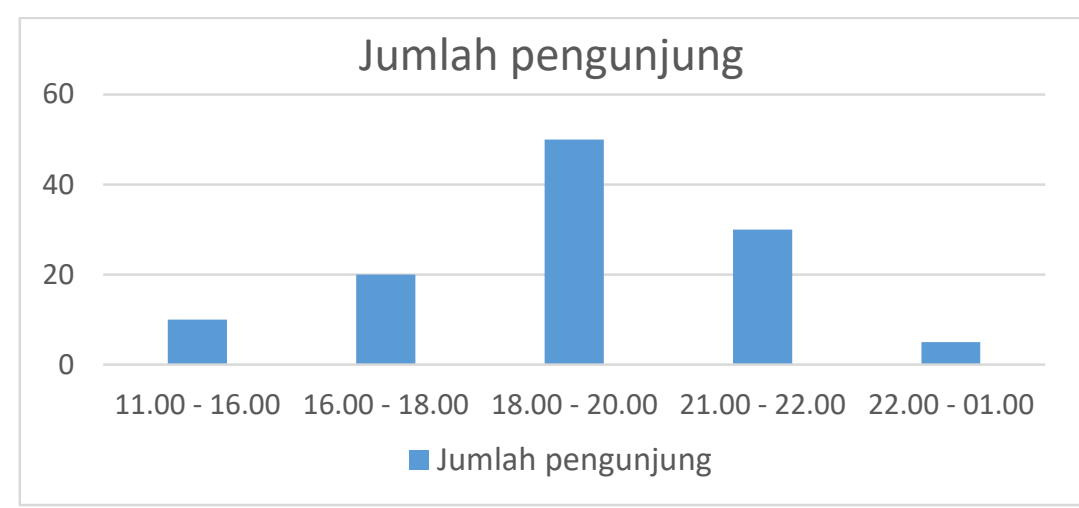

Grafik (5.1) Grafik jumlah pengunjung

Sumber: Penulis, 2017

Dilihat dari hasil grafik 5.1 maka jumlah pengunjung terbanyak terjadi pada rentang 16.00 hingga $22.00 \mathrm{WIB}$, dimana puncak pengunjung paling tinggi terjadi saat pukul $18.00-22.00 \mathrm{WIB}$. 

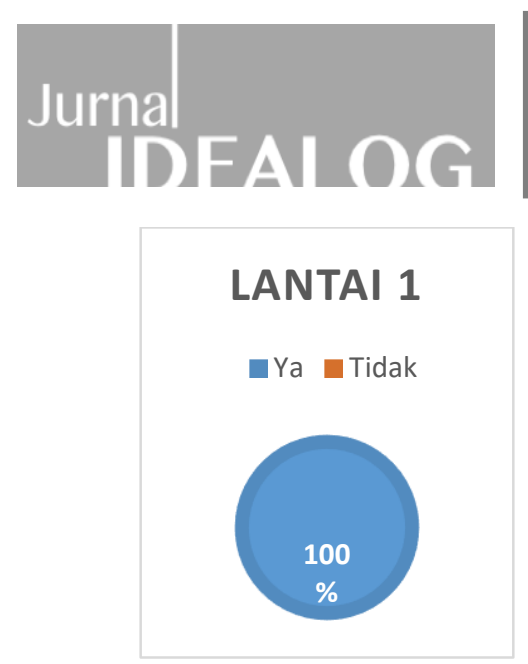

Grafik (5.3) Grafik hasil interview

Sumber: Penulis, 2017

Grafik (5.2) Grafik hasil interview

Sumber: Penulis, 2017

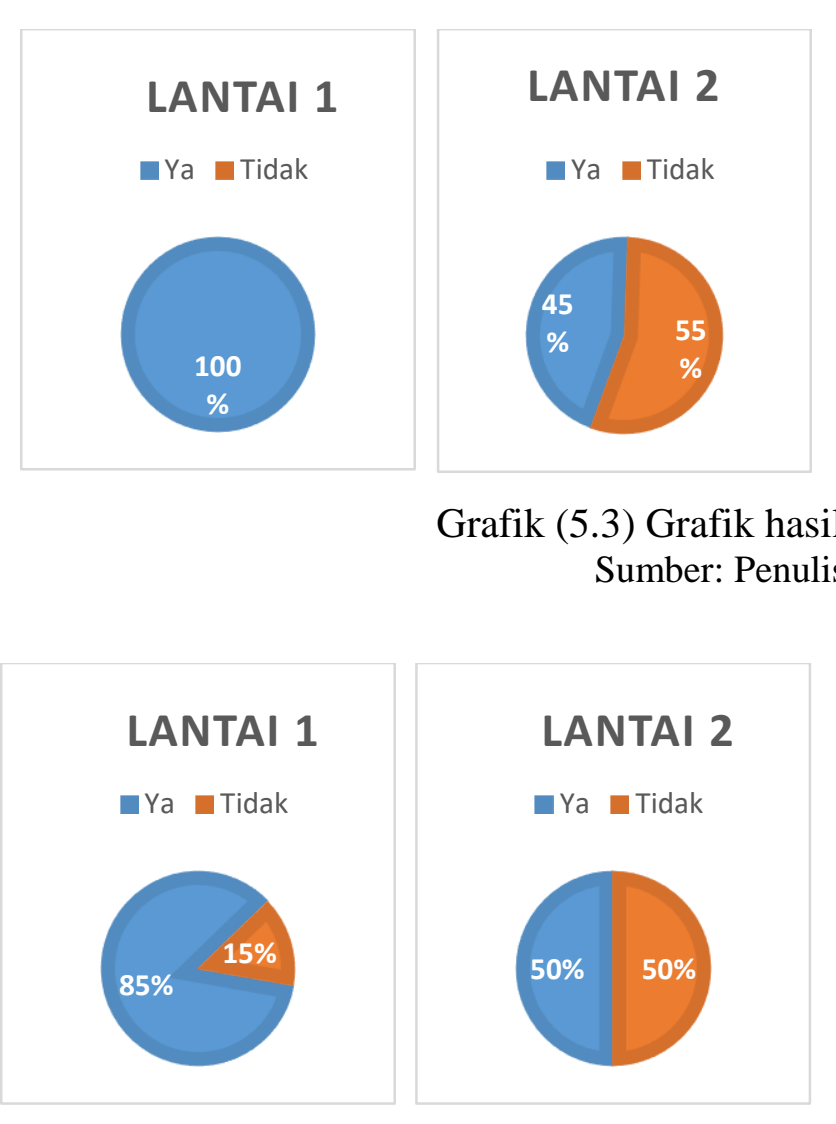

Apakah kesan cahaya lampu pada malam hari yang mereka tempati untuk melakukan kegiatan pada restoran cukup terang?

Hasil dari grafik dapat dilihat bahwa lantai satu lebih memenuhi standar keterangan bagi pengunjung sebanyak $100 \%$ dari pada lantai dua yang hanya $35 \%$.

Apakah lampu yang digunakan pada malam hari memberikan kenyamanan di mata?

Pada grafik ini $100 \%$ pengunjung lebih nyaman menggunakan lampu pada area lantai satu dibandingkan lantai dua yang hanya $45 \%$ saja yang setuju.

\begin{abstract}
Apakah cahaya lampu yang digunakan pada malam hari memberikan kesan hangat dan riang?

Grafik disamping menunjukan lampu $85 \%$ setuju pada lantai satu lebih memberikan kesan hangat dan riang dibandingkan dengan lantai dua yang hanya sebagian yang setuju.
\end{abstract}

Grafik (5.4) Grafik hasil interview Sumber: Penulis, 2017 

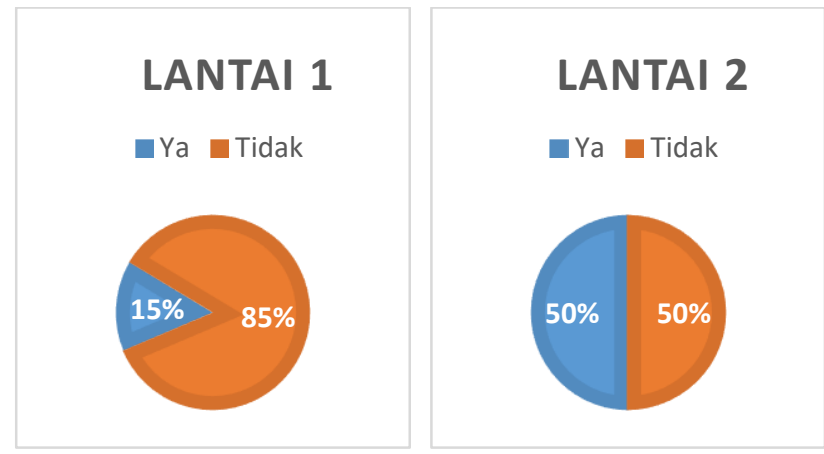

Apakah cahaya lampu yang digunakan pada malam hari memberikan kesan tenang dan romantis?

Dari hasil grafik ini lampu pada lantai dua lebih banyak dipilih memberikan kesan tenang dan romantic dari pada lantai satu.

Grafik (5.5) Grafik hasil interview Sumber: Penulis, 2017
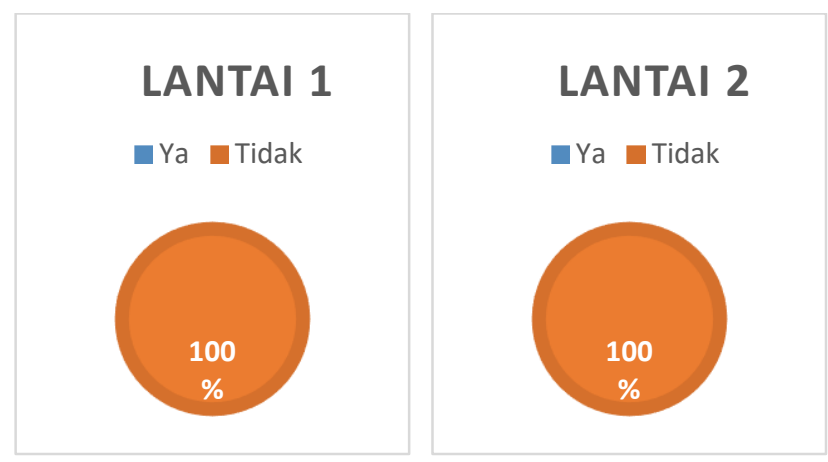
Apakah cahaya lampu yang digunakan pada malam hari memberikan kesan tenang dan dingin?

Grafik menunjukan lampu pada kedua lantai tidak memberikan kesan tenang dan dingin.

Grafik (5.6) Grafik hasil interview Sumber: Penulis, 2017

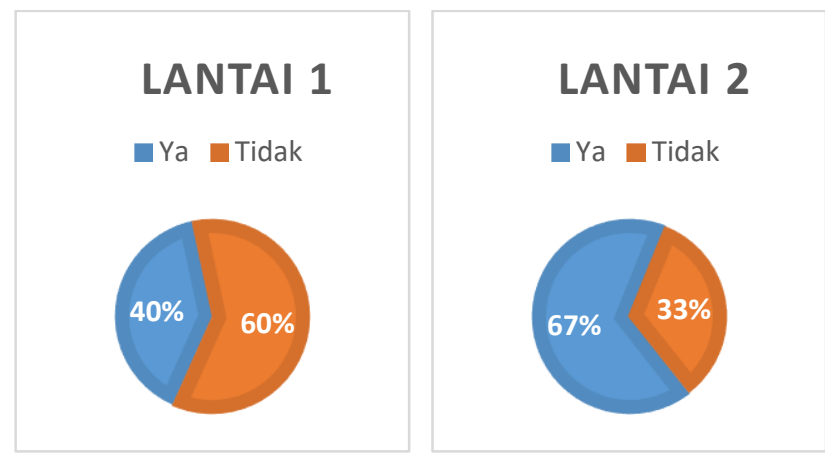

Apakah cahaya lampu yang digunakan pada malam hari memberikan silau pada saat beraktifitas? (contoh: cahaya yang dipantulkan pada meja makan terlalu silau)

Hasil grafik menunjukan pada lantai satu dari 25 pengguna, 10 pengguna mengatakan bahwa cahaya lampu cukup silau. Untuk lantai dua dari 15 pengguna, 11 mengatakan cahaya lampu cukup silau. Ini bisa disebabkan penerapan lampu yang kurang tepat atau terlalu dekat dengan meja.

Grafik (5.7) Grafik hasil interview

Sumber: Penulis, 2017 


\subsection{Hasil Pengukuran}

Pengukuran dilakukan sesuai titik - titik lampu dan posisi duduk pengguna di restoran Atmosphere. Dari hasil observasi, survei, dan hasil pengukuran maka bisa didapat yaitu luas ruang sebesar 12 meter x 21 meter per lantai yang dimana terdapat zona sebanyak 28 titik pada lantai satu dan 18 titik pada lantai dua. Zona pertitik itu yang akan menjadi posisi duduk dan titik lampu restoran. Pengukuran dilakukan pada pukul 19.00 s/d 20.00 WIB.

Area yang dibagi dalam pengukuran titik lampu ada 2 macam, yaitu area makan dan area void. Ada beberapa faktor yang menjadi pertimbangan utama dalam pengukuran:

- Jenis lampu dan luminer pada radius $9 \mathrm{~m}^{2}$ pada titik pengukuran akan mempengaruhi tinggi rendahnya intensitas.

- Pada titik yang dekat dengan jendela biasanya mempunyai intensitas cahaya lebih rendah dibandingkan dengan ruangan tengah. Hal itu bisa disebabkan karena material kaca atau jendela yang memungkinkan cahaya berpendar keluar ruang.

- Material pada ruang akan mempengaruhi pengguna dalam mempersepsikan kecerahan ruang.
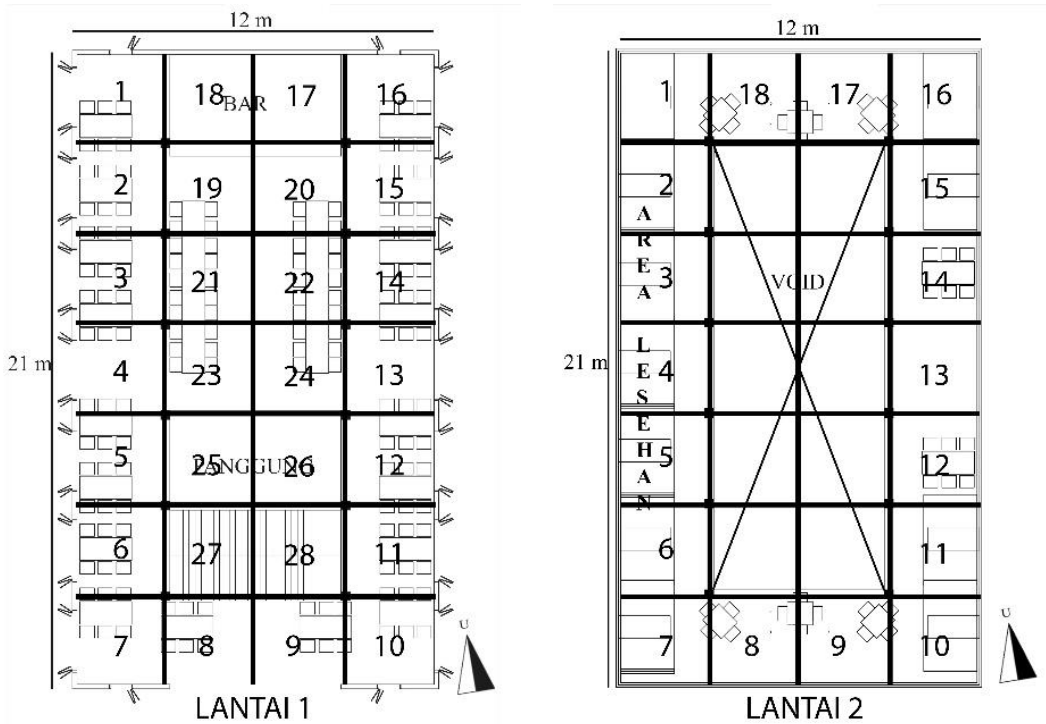

Gambar (5.1) Pembagian titik dan zona pengukaran

Sumber: Penulis, 2017

Dari hasil pengamatan zona void pada titik 19 sampai titik 28 pada lantai satu dan dua mempunyai penerangan yang baik karena berada ditengah ruang dan mendapatkan pencahayaan yang lebih terang. Maka dengan itu pengukuran dilakukan pada dua zona pada tiap lantai restoran menggunakan alat ukur luxmeter, dengan pengukuran lapangan menggunakan dua variable untuk proses pengambilan data:

1. Jenis lampu yang terdapat disekitar titik pengukuran dengan radius $9 \mathrm{~m}^{2}$.

2. Jenis armatur berdasarkan arah cahaya.

Dengan hasil pengukuran sebagai berikut: 


\begin{tabular}{|c|c|c|c|}
\hline $\begin{array}{c}\text { Nomor } \\
\text { Titik }\end{array}$ & $\begin{array}{l}\text { Hasil } \\
\text { Pengukuran } \\
\text { (lux) }\end{array}$ & $\begin{array}{c}\text { Jenis lampu yang terdapat } \\
\text { disekitar titik pengukuran } \\
\text { dengan radius } 9 \mathrm{~m}^{2} .\end{array}$ & $\begin{array}{c}\text { Jenis armature berdasarkan } \\
\text { arah cahaya }\end{array}$ \\
\hline 1. & 45.41 & $\begin{array}{l}\text { LED strip warm light } \\
2 \text { LED warm light }\end{array}$ & $\begin{array}{l}\text { Semi langsung } \\
\text { Langsung }\end{array}$ \\
\hline 2 & 46.85 & $\begin{array}{l}\text { LED strip warm light } \\
\text { LED warm light }\end{array}$ & $\begin{array}{l}\text { Semi langsung } \\
\text { Langsung }\end{array}$ \\
\hline 3 & 34.43 & $\begin{array}{l}\text { LED strip warm light } \\
\text { LED warm light }\end{array}$ & $\begin{array}{l}\text { Semi langsung } \\
\text { Langsung }\end{array}$ \\
\hline 4 & 47.65 & $\begin{array}{l}\text { LED strip warm light } \\
\text { LED warm light }\end{array}$ & $\begin{array}{l}\text { Semi langsung } \\
\text { Langsung }\end{array}$ \\
\hline 5 & 46.45 & $\begin{array}{l}\text { LED strip warm light } \\
\text { LED warm light }\end{array}$ & $\begin{array}{l}\text { Semi langsung } \\
\text { Langsung }\end{array}$ \\
\hline 6 & 46.68 & $\begin{array}{l}\text { LED strip warm light } \\
\text { LED warm light }\end{array}$ & $\begin{array}{l}\text { Semi langsung } \\
\text { Langsung }\end{array}$ \\
\hline 7 & 40.02 & $\begin{array}{l}\text { LED strip warm light } \\
2 \text { LED warm light }\end{array}$ & $\begin{array}{l}\text { Semi langsung } \\
\text { Langsung }\end{array}$ \\
\hline 8 & 89.41 & $\begin{array}{l}\text { LED strip warm light } \\
\text { LED warm light }\end{array}$ & $\begin{array}{l}\text { Semi langsung } \\
\text { Langsung }\end{array}$ \\
\hline 9 & 89.20 & $\begin{array}{l}\text { LED strip warm light } \\
\text { LED warm light }\end{array}$ & $\begin{array}{l}\text { Semi langsung } \\
\text { Langsung }\end{array}$ \\
\hline 10 & 47.04 & $\begin{array}{l}\text { LED strip warm light } \\
2 \text { LED warm light }\end{array}$ & $\begin{array}{l}\text { Semi langsung } \\
\text { Langsung }\end{array}$ \\
\hline 11 & 42.65 & $\begin{array}{l}\text { LED strip warm light } \\
\text { LED warm light }\end{array}$ & $\begin{array}{l}\text { Semi langsung } \\
\text { Langsung } \\
\end{array}$ \\
\hline 12 & 45.63 & $\begin{array}{l}\text { LED strip warm light } \\
\text { LED warm light }\end{array}$ & $\begin{array}{l}\text { Semi langsung } \\
\text { Langsung }\end{array}$ \\
\hline 13 & 39.06 & $\begin{array}{l}\text { LED strip warm light } \\
\text { LED warm light }\end{array}$ & $\begin{array}{l}\text { Semi langsung } \\
\text { Langsung }\end{array}$ \\
\hline 14 & 45.28 & $\begin{array}{l}\text { LED strip warm light } \\
\text { LED warm light }\end{array}$ & $\begin{array}{l}\text { Semi langsung } \\
\text { Langsung }\end{array}$ \\
\hline 15 & 43.29 & $\begin{array}{l}\text { LED strip warm light } \\
\text { LED warm light }\end{array}$ & $\begin{array}{l}\text { Semi langsung } \\
\text { Langsung }\end{array}$ \\
\hline 16 & 35.06 & $\begin{array}{l}\text { LED strip warm light } \\
2 \text { LED warm light }\end{array}$ & $\begin{array}{l}\text { Semi langsung } \\
\text { Langsung }\end{array}$ \\
\hline 17 & 70.26 & $\begin{array}{l}3 \text { Incandescent warm light } \\
\text { LED strip warm light } \\
\text { CFL warm light } \\
\text { LED warm light }\end{array}$ & $\begin{array}{l}\text { Langsung } \\
\text { Semi langsung } \\
\text { Semi langsung } \\
\text { Langsung }\end{array}$ \\
\hline 18 & 70.62 & $\begin{array}{l}3 \text { Incandescent warm light } \\
\text { LED strip warm light } \\
\text { CFL warm light } \\
\text { LED warm light }\end{array}$ & $\begin{array}{c}\text { Langsung } \\
\text { Semi langsung } \\
\text { Semi langsung } \\
\text { Langsung }\end{array}$ \\
\hline
\end{tabular}

Tabel (5.1) Hasil pengukuran dan analisa tingkat penerangan area makan lantai satu dengan luxmeter

Sumber: Penulis, 2017 


\begin{tabular}{|c|c|c|c|}
\hline $\begin{array}{l}\text { Nomor } \\
\text { Titik }\end{array}$ & $\begin{array}{l}\text { Hasil } \\
\text { Pengukuran } \\
\quad \text { (lux) }\end{array}$ & $\begin{array}{c}\text { Jenis lampu yang terdapat } \\
\text { disekitar titik pengukuran } \\
\text { dengan radius } 9 \mathrm{~m}^{2} \text { area void. }\end{array}$ & $\begin{array}{c}\text { Jenis armature berdasarkan } \\
\text { arah cahaya }\end{array}$ \\
\hline 19 & 29.86 & $\begin{array}{l}3 \text { Incandescent warm light } \\
2 \text { CFL warm light } \\
2 \text { LED warm light } \\
2 \text { LED warm light }\end{array}$ & $\begin{array}{c}\text { Langsung } \\
\text { Semi langsung } \\
\text { Langsung } \\
\text { Tidak langsung }\end{array}$ \\
\hline 20 & 28.94 & $\begin{array}{l}3 \text { Incandescent warm light } \\
2 \text { CFL warm light } \\
2 \text { LED warm light } \\
2 \text { LED warm light }\end{array}$ & $\begin{array}{l}\text { Langsung } \\
\text { Semi langsung } \\
\text { Langsung } \\
\text { Tidak langsung }\end{array}$ \\
\hline 21 & 37.64 & $\begin{array}{l}2 \text { CFL warm light } \\
2 \text { LED warm light } \\
2 \text { LED warm light } \\
\text { LED warm light }\end{array}$ & $\begin{array}{l}\text { Semi langsung } \\
\text { Langsung } \\
\text { Tidak langsung } \\
\text { Langsung }\end{array}$ \\
\hline 22 & 37.20 & $\begin{array}{l}2 \text { CFL warm light } \\
2 \text { LED warm light } \\
2 \text { LED warm light } \\
\text { LED warm light }\end{array}$ & $\begin{array}{l}\text { Semi langsung } \\
\text { Langsung } \\
\text { Tidak langsung } \\
\text { Langsung }\end{array}$ \\
\hline 23 & 105.23 & $\begin{array}{l}2 \text { CFL warm light } \\
2 \text { LED warm light } \\
2 \text { LED warm light } \\
2 \text { LED warm light }\end{array}$ & $\begin{array}{l}\text { Semi langsung } \\
\text { Langsung } \\
\text { Tidak langsung } \\
\text { Langsung }\end{array}$ \\
\hline 24 & 106.05 & $\begin{array}{l}2 \text { CFL warm light } \\
2 \text { LED warm light } \\
2 \text { LED warm light } \\
2 \text { LED warm light }\end{array}$ & $\begin{array}{l}\text { Semi langsung } \\
\text { Langsung } \\
\text { Tidak langsung } \\
\text { Langsung }\end{array}$ \\
\hline 25 & 105.83 & $\begin{array}{l}2 \text { CFL warm light } \\
2 \text { LED warm light } \\
2 \text { LED warm light } \\
2 \text { LED warm light }\end{array}$ & $\begin{array}{l}\text { Semi langsung } \\
\text { Langsung } \\
\text { Tidak langsung } \\
\text { Langsung }\end{array}$ \\
\hline 26 & 105.30 & $\begin{array}{l}2 \text { CFL warm light } \\
2 \text { LED warm light } \\
2 \text { LED warm light } \\
2 \text { LED warm light }\end{array}$ & $\begin{array}{l}\text { Semi langsung } \\
\text { Langsung } \\
\text { Tidak langsung } \\
\text { Langsung }\end{array}$ \\
\hline 27 & 69.28 & $\begin{array}{l}2 \text { CFL warm light } \\
2 \text { LED warm light } \\
2 \text { LED warm light } \\
\text { LED warm light }\end{array}$ & $\begin{array}{l}\text { Semi langsung } \\
\text { Langsung } \\
\text { Tidak langsung } \\
\text { Langsung }\end{array}$ \\
\hline 28 & 69.67 & $\begin{array}{l}2 \text { CFL warm light } \\
2 \text { LED warm light } \\
2 \text { LED warm light } \\
\text { LED warm light }\end{array}$ & $\begin{array}{l}\text { Semi langsung } \\
\text { Langsung } \\
\text { Tidak langsung } \\
\text { Langsung }\end{array}$ \\
\hline
\end{tabular}

Tabel (5.2) Hasil pengukuran dan analisa tingkat penerangan area void lantai satu dengan luxmeter

Sumber: Penulis, 2017 


\begin{tabular}{|c|c|c|c|}
\hline $\begin{array}{c}\text { Nomor } \\
\text { Titik }\end{array}$ & $\begin{array}{l}\text { Hasil } \\
\text { Pengukuran } \\
\text { (lux) }\end{array}$ & $\begin{array}{l}\text { Jenis lampu yang terdapat } \\
\text { disekitar titik pengukuran } \\
\text { dengan radius } 9 \mathrm{~m}^{2} \text {. }\end{array}$ & $\begin{array}{c}\text { Jenis armature berdasarkan } \\
\text { arah cahaya }\end{array}$ \\
\hline 1. & 18.25 & $\begin{array}{c}\text { CFL warm light } \\
\text { LED warm light } \\
\text { 4 LED warm light }\end{array}$ & $\begin{array}{c}\text { Membaur } \\
\text { Langsung } \\
\text { Tidak langsung } \\
\end{array}$ \\
\hline 2 & 19.83 & $\begin{array}{l}2 \text { CFL warm light } \\
\text { LED warm light } \\
\text { 4 LED warm light }\end{array}$ & $\begin{array}{c}\text { Membaur } \\
\text { Langsung } \\
\text { Tidak langsung }\end{array}$ \\
\hline 3 & 18.01 & $\begin{array}{l}\text { 2 CFL warm light } \\
\text { LED warm light } \\
\text { 4 LED warm light }\end{array}$ & $\begin{array}{c}\text { Membaur } \\
\text { Langsung } \\
\text { Tidak langsung }\end{array}$ \\
\hline 4 & 17.03 & $\begin{array}{l}2 \text { CFL warm light } \\
\text { LED warm light } \\
\text { 4 LED warm light }\end{array}$ & $\begin{array}{c}\text { Membaur } \\
\text { Langsung } \\
\text { Tidak langsung }\end{array}$ \\
\hline 5 & 19.45 & $\begin{array}{l}2 \text { CFL warm light } \\
\text { LED warm light } \\
\text { 4 LED warm light } \\
\end{array}$ & $\begin{array}{c}\text { Membaur } \\
\text { Langsung } \\
\text { Tidak langsung } \\
\end{array}$ \\
\hline 6 & 17.64 & $\begin{array}{l}2 \text { CFL warm light } \\
\text { LED warm light } \\
\text { 4 LED warm light }\end{array}$ & $\begin{array}{c}\text { Membaur } \\
\text { Langsung } \\
\text { Tidak langsung }\end{array}$ \\
\hline 7 & 17.67 & $\begin{array}{l}\text { CFL warm light } \\
\text { LED warm light } \\
\text { 4 LED warm light }\end{array}$ & $\begin{array}{c}\text { Membaur } \\
\text { Langsung } \\
\text { Tidak langsung }\end{array}$ \\
\hline 8 & 17.43 & $\begin{array}{c}\text { LED warm light } \\
2 \text { LED warm light }\end{array}$ & $\begin{array}{c}\text { Langsung } \\
\text { Tidak langsung }\end{array}$ \\
\hline 9 & 18.05 & $\begin{array}{l}\text { LED warm light } \\
2 \text { LED warm light }\end{array}$ & $\begin{array}{c}\text { Langsung } \\
\text { Tidak langsung } \\
\end{array}$ \\
\hline 10 & 17.86 & $\begin{array}{l}\text { CFL warm light } \\
\text { LED warm light } \\
\text { 4 LED warm light }\end{array}$ & $\begin{array}{c}\text { Membaur } \\
\text { Langsung } \\
\text { Tidak langsung }\end{array}$ \\
\hline 11 & 19.02 & $\begin{array}{l}2 \text { CFL warm light } \\
\text { LED warm light } \\
\text { 4 LED warm light }\end{array}$ & $\begin{array}{c}\text { Membaur } \\
\text { Langsung } \\
\text { Tidak langsung } \\
\end{array}$ \\
\hline 12 & 25.27 & $\begin{array}{l}\text { LED warm light } \\
4 \text { LED warm light }\end{array}$ & $\begin{array}{c}\text { Langsung } \\
\text { Tidak langsung }\end{array}$ \\
\hline 13 & 24.02 & $\begin{array}{l}\text { LED warm light } \\
4 \text { LED warm light }\end{array}$ & $\begin{array}{c}\text { Langsung } \\
\text { Tidak langsung }\end{array}$ \\
\hline 14 & 25.02 & $\begin{array}{l}\text { LED warm light } \\
4 \text { LED warm light }\end{array}$ & $\begin{array}{c}\text { Langsung } \\
\text { Tidak langsung } \\
\end{array}$ \\
\hline 15 & 19.48 & $\begin{array}{l}2 \text { CFL warm light } \\
\text { LED warm light } \\
\text { 4 LED warm light } \\
\end{array}$ & $\begin{array}{c}\text { Membaur } \\
\text { Langsung } \\
\text { Tidak langsung } \\
\end{array}$ \\
\hline 16 & 18.86 & $\begin{array}{l}\text { CFL warm light } \\
\text { LED warm light } \\
\text { 4 LED warm light }\end{array}$ & $\begin{array}{c}\text { Membaur } \\
\text { Langsung } \\
\text { Tidak langsung }\end{array}$ \\
\hline 17 & 17.47 & $\begin{array}{c}\text { LED warm light } \\
2 \text { LED warm light }\end{array}$ & $\begin{array}{c}\text { Langsung } \\
\text { Tidak langsung } \\
\end{array}$ \\
\hline 18 & 18.11 & LED warm light & Langsung \\
\hline
\end{tabular}




\begin{tabular}{|l|l|l|l|}
\hline & & 2 LED warm light & Tidak langsung \\
\hline
\end{tabular}

Tabel (5.3) Hasil pengukuran dan analisa tingkat penerangan area makan lantai dua dengan luxmeter

Sumber: Penulis, 2017

Dari data diatas dapat dilihat angka yang merupakan hasil pengukuran tiap daerah yang mempunyai intensitas cahaya yang rendah, sedang dan tinggi. Angka tersebut dibagikan menjadi 3 kelompok seperti berikut:

1. Kelompok cahaya intensitas rendah: range $00.00-34.00$ lux

2. Kelompok cahaya intensitas sedang: range $35.00-69.00$ lux

3. Kelompok cahaya intensitas tinggi: range $70.00-106.00$ lux

Didapat hasil visual kontur iluminasi hasil pengukuran tingkat intensitas cahaya pada ruang restoran Atmosphere sebagai berikut:
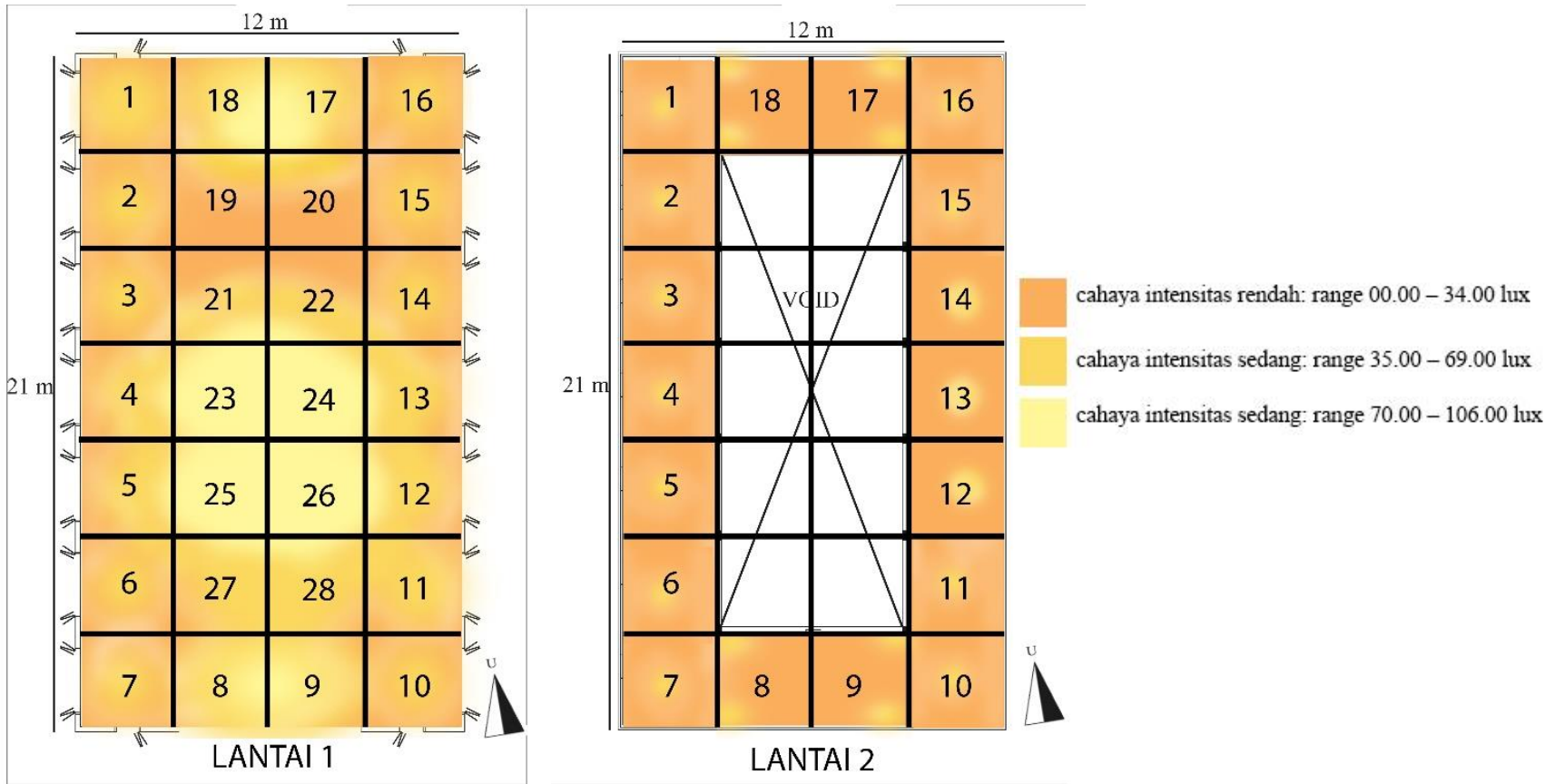

Gambar (5.2) Kontur iluminasi pada layout denah titik pengukuran Sumber: Penulis, 2017

Untuk hasil survey untuk zona duduk didapatkan bahwa pada zona pada titik $1-7,10-$ 16, dan 19 - 24 di lantai satu merupakan bagian zona yang paling banyak digunakan pada malam hari. Sedangkan pada lantai dua zona pada titik 12 dan 14 yang paling sering digunakan. Dalam segi penerapan cahaya lantai satu hampir semuanya memiliki pencahayaan general yang banyak dan cukup terang, dibandingkan dengan lantai dua yang lebih banyak memiliki pencahayaan khusus.

\section{Hasil Pembahasan}

Dari hasil penelitian "Penerapan Pencahayaan Buatan Pada Interior Restoran Atmosphere Bandung Di Malam Hari” ditemukan bahwa:

1. Penerapan pencahayaan buatan pada malam hari di lantai satu memiliki pencahayaan general dan khusus yang cukup bagus sehingga memiliki kondisi cukup terang. Pada 
lantai dua penerapan pencahayaan general masih kurang sehingga memiliki kondisi ruang yang gelap.

2. Dari hasil dan suasana yang dirasakan pengunjung, maka bisa dilihat bahwa lantai satu yang memiliki pencahayaan general yang lebih banyak dengan cahaya yang cukup terang memberikan suasan hangat dan riang. Untuk lantai dua yang lebih memiliki lampu khusus yang banyak memberikan pencahayaan yang redup menjadikan suasana tenang dan romantis. Lantai satu lebih sering digunakan pada malam hari dibandingkan dengan lantai dua. Maka bisa dilihat bahwa pengunjung lebih memilih suasana hangat dan riang yang lebih dimiliki pada lantai satu dibandingkan lantai dua. Lantai dua yang memiliki suasana tenang dan romantis hanya digunakan beberapa pengunjung saja.

3. Himpunan cahaya dari intensitas rendah hingga sedang terdapat pada titik daerah makan dekat jendela lantai satu dan dua sebagai berikut:

- Intensitas cahaya rendah rendah berada pada titik 1 - 18 pada lantai dua, titik 19 dan 20 pada lantai satu.

- Intensitas cahaya sedang berada pada titik 1-7, 10-16, 21, 22 dan 28 lantai satu.

Sedangkan intensitas cahaya tinggi sebesar dengan range 70.00 - 106.00 lux terdapat pada daerah panggung restoran yang berada di tengah ruang pada titik $8,9,18,17,19$, dan 23 - 26 pada lantai satu, walaupun begitu daerah tersebut masih dibawah standar kenyamanan ruang makan yaitu 120-250 lux untuk kegiatan aktivitas

4. Kenyaman visual salah satunya dipengaruhi oleh rendesari warna dari colour temperature pada lampu. Dalam menentukan kenyamanan visual jika pencahayaan kebutuhan ruang rendah, maka lampu mempunyai colour temperature yang rendah yaitu warm white. Jika pencahayaan kebutuhan ruang tinggi, maka lampu mempunyai colour temperature yang tinggi (cool light). Dari hasil observasi di lapangan diperoleh bahwa semua ruang pada ruang makan restoran Atmosphere mempunyai colour temperature warm light. Restoran ini memakai warna warm light untuk memberikan kesan hangat dan suasana Bali, tetapi kebutuhan cahaya yang diperlukan untuk standar kurang terpenuhi. Hal ini bisa diubah dengan penambahan titik lampu dan mengubah beberapa lampu fluorescent dengan range colour temperature $3300 \mathrm{~K}-5300$ Kelvin.

5. Pada restoran terdapat dua lantai, yaitu lantai satu area duduk biasa dan lantai dua untuk area lesehan. Pada area lesehan yang mempunyai pencahayaan paling rendah membutuhkan penerangan besar dengan salah satu solusi seperti memberi general lighting yang mempunyai colour temperature metal halide pada titik $1-7$, dan $10-16$ pada lantai dua.

6. Pada area lesehan pada lantai dua lebih memiliki silau yang lebih tinggi terutama di area lesehan. Silau bisa diatasi dengan mengganti besar cahaya lampu atau mengatur tinggi atau tata letak sumber cahaya dan pantulannya terhadap penglihatan pengguna.

\section{Kesimpulan}

Restoran Atmosphere telah melakukan banyak terapan tata pencahayaan untuk interiornya, terapan itu bisa dilihat pada penjelasan aspek yang telah dijelaskan. Dari penerapan cahaya buatan biasa dilihat bahwa beberapa penerapan cahaya pada restoran memiliki efek dan pengaruh tertentu untuk penggunanya. Pada malam hari daerah yang sering digunakan berupa daerah lantai satu yang memiliki suasana hangat dan riang. Berbeda dengan lantai satu, lantai dua dengan suasana romantis lebih sedikit dinikmati oleh pengunjung, dikarenakan daerah yang terlalu redup lebih dinikmati oleh pengunjung yang berpasangan. 
Sedangkan untuk penerapan cahaya buatan restoran Atmosphere cenderung gelap karena pencahayaan umum yang minim dan kebanyakan memakai colour temperature warm white pada beberapa zona di restoran terutama pada lantai dua sehingga tidak memenuhi standar penerangan bangunan. Hasil pengukuran ruangan menggunakan luxmeter tidak sesuai dengan syarat penerangan bangunan berdasarkan SNI-03-6575-2001 tentang Tata Cara Sistem Pengcahayaan Buatan pada Bangunan Gedung, sedangakan standar yang direkomendasikan untuk bangunan ini adalah $120-250$ lux.

Restoran ini lebih cenderung menerapkan pencahayaan khusus seperti spot light, pendant light, LED strip, dan wall lamp dengan warna warm light pada langit-langit dan dinding restoran yang dapat mengekspos suasana dan identitas yang diinginkan, tapi dari segi kenyamanan dalam beraktifitas dan perihal lainnya dalam ruang bisa dibilang belum terlalu tercapai. Dari hasil kelebihan dan kekurangan aspek yang telah ditemukan maka sebaiknya pencahayaan buatan pada interior restoran Atmosphere yang berupa pencahayaan umum dan pencahayaan khusus lebih diterapkan dan dipadukan secara fungsional dan estetika yang lebih baik lagi. Pencahayaan pada area yang terlalu gelap bisa diatasi dengan pemberian pencahayaan umum dengan jenis lain, menambahkan pencahayaan umum, atau mengganti intensitas cahaya lebih tinggi pada lampu kertas gantung pada lantai dua. Selain pemberian cahaya umum bisa juga dengan memberikan cahaya khusus pada area-area tertentu yang membutuhkan cahaya lebih dan mengganti letak beberapa penerapan cahaya khusus untuk meminimalisir cahaya silau.

\section{Daftar Pustaka}

[1.] Darmasetiawan, Christian., dan Lestari Puspakesuma. (1991). Teknik Pencahayaan dan Tata Letak Lampu, Jilid 1. Jakarta: Gramedia Widiasarana.

[2.] Panero, Julius., dan Martin Zelnik. (2003). Dimensi Manusia dan Ruang Interior, Terjemahan. Jakarta: Erlangga.

[3.] Pile, F John. (2002). Interior Design. New York: Harry N. Abrams

[4.] Notebook, DI. (2013). Isi Lighting. Universitas UNIKOM. http://di.unikom.ac.id/isi_lighting.pdf (diakses tanggal 26 Agustus 2016).

[5.] Saputra, Nugraha., \& Edwin Widia. (2014). Analisa Tata Pencahayaan Interior Kafe Cocorio di Bandung. Institut Teknologi Nasional. jurnalonline.itenas.ac.id/index.php/rekajiva/article/download/375/543 (diakses tanggal 26 Agustus 2017)

[6.] Soegandhi, Steffi., Hedy C. Indrani., dan Purnama Esa Dora. (2015). Optimasi Sistem Pencahayaan Buatan pada Budget Hotel di Surabaya. Universitas Kristen Petra. http://studentjournal.petra.ac.id/index.php/desain-interior/article/view/3493/3163 (diakses tanggal 26 Agustus 2017)

[7.] Marysa, Intan Hannah, dan Aria Wenny A. (2016). Studi Pengaruh Warna pada Interior Terhadap Psikologis Penggunanya, Studi Kasus pada Unit Transfusi Darah Kota $\quad$ X. Institut Teknologi Sepuluh Nopember. iptek.its.ac.id/index.php/jdi/article/download/1461/1235 (diakses tanggal 26 Agustus 2017)

[8.] SNI 03-6575-2001. 2001. Tata Cara Sistem Pengcahayaan Buatan pada Bangunan Gedung. 
Jurnal I D E A L O G

Ide dan Dialog Indonesia

Vol.2 No.1, April 2017

ISSN Cetak 2477- 0566

ISSN Elektronik 2615 - 6776 